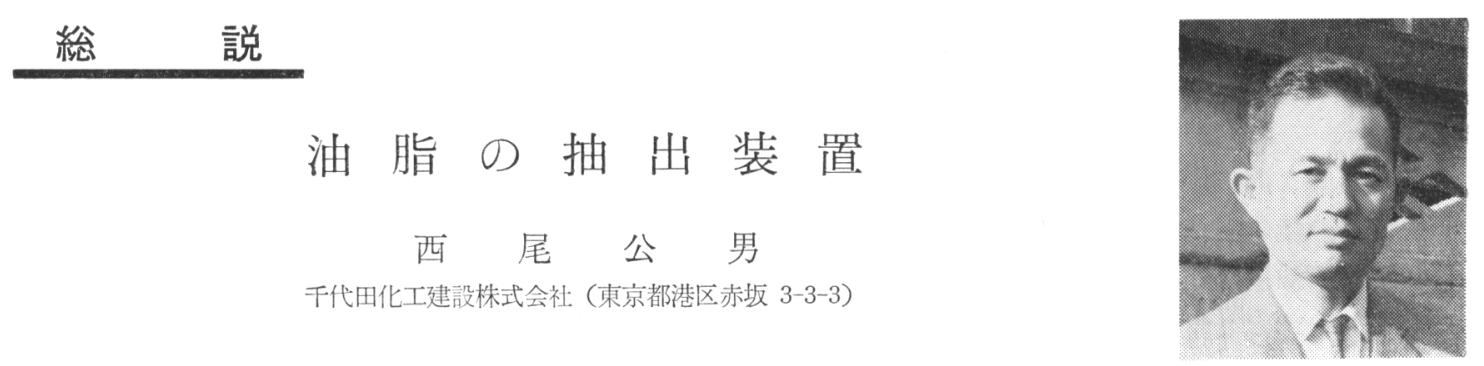

\title{
Continious Solvent Extraction Plant of Vegetable Oil
}

Kimio Nishio

Chiyoda Chemical Engineering \& Construction Co. Ltd. (3-3, 3-chōme, Akasaka, Minato-ku, Tokyo)

\section{ま えがき}

油脂の抽出といら場合, 油脂源から大別した植物性油 脂と動物性油脂, 採取法より大別した融出法 (rendering), 圧搾法 (pressing) 溶剤抽出法 (solvent extraction）および圧搾法と溶剂抽出法を結合した圧抽法 (prepress-solvent extraction) があるが，ここでは油脂 抽出の主体をなす植物性油脂の連続抽出装置に対象を絞 り述べる。

説明の順序として, まず最近の植物油脂抽出装置の概 観をし, 続いて, 連続抽出装置につき概説をしたあと, 終わりに一昨年暮著者の会社で西独エキステクニク社 (Extechnik 社) とカローザル抽出装置 (Carrousel-extration plant）につき技術提携したので，このカローザ ル抽出装置につき紹介したい。

\section{1 最近の植物油脂抽出装置の概観}

最近における植物油脂抽出装置を概観すると, 国際的 な競争の激化や労働力の不足, 漸増する製品需要, とく に脱脂大豆消費の急増などの諸状勢に対応し, 合理化の 急務から装置の連続化, 自動化に加えとくに設備規模の 大型化傾向が目立っている。

わが国でも昭和 30 年ころよりデスメット型 (De Smet type) ロートセル型 (Rotocel type) ルルギ型 (Lurgi type）などの高性能連続抽出装置が相ついで導入される 一方, 国産でも千代田型, 吉野型などの連続抽出装置が 建設され大豆を中心として装置の連続化自動化が行なわ れ, 最近大豆については, 特殊用途を除きほとんど連続 化されるに至った。また昨年来大豆は需要漸増に伴う増 設期にも当たり各社の設備投資企画が活発になっている ようであるが，既設の設備の処理能力は一台当たり 100 $-1000 \mathrm{t} /$ 日（大豆として）であるのに比し, 今度は一台 当たりの処理能力が $1500 \mathrm{t} /$ 日（大豆として）という国 際規模の大型設備が本年中にも実現されるようである。 一方雑穀についても, 需要の激増に伴ら設備桩大に対
応し，原料またはプレスケーキの連続抽出が増加して㧍 り, ヌカの連続抽出 (浸セキ型, 貫流型ともに稼動して (る), ゴマ, ヒマシの直接抽出, その他プレスケーキ の連続抽出が行なわれるようになった。

こうした合理化とくに大型化の進展につれ，製造技術 の面でも, 抽出装置の進歩があることはいらまでもない が，乙かし著者の知る範囲では, 昭和 30 年当時に見ら れたような画期的なものは見当たらず，抽出装置の基本 型は現今でも 4 5 年前とあまり変わりないようで, 技 術の方向は（1）従前の基本型を土台とした大型化, (2) 多様な性質を持つ各雑穀のより経済的な連続抽出技 術の開発のように思われる。

\section{2 連続抽出装置}

前項に述べた理由により，ここで述べることも旧聞に 属することが多いが，わが国にとり主要な油脂原料を中 心に, 前処理工程一抽出工程につき, 工程順に概説する。 まずわが国における植物油脂原料の処理量を昭和 35 年 および最近の $2 \sim 3$ 年につき概数を 表- $1^{1)}$ に示す。

表-1 に見られるように, わが国の植物油脂原料中大 豆の占める比率はきわめて大きく, ナタネ, サフラワ 一, ヌカなどがこれに続いている。ヌカは国内産の重要 な油脂源で，対資源の利用度も順次上昇している。この ほか綿実，ゴマ，パーム核などが処理されているが、こ れらの各原料の含油量および形状を示すと表-2の上お りである。また各原料の主採油法はつぎのとおり。

大 豆; 連続溶剤抽出法

ヌカ; 連続または回分溶剤抽出法（連続が増加して (る)

その他；圧搾法だけまた法圧抽法であるがゴマについ ては連続式の直接抽出も行なわれているよう である。

$2 \cdot 1$ 前処理工程 ${ }^{2) ~ 6)}$

植物種子の抽出において, 前処理操作は製品として得 られる油脂および抽出カスの品質, 油の収率, 抽出操作 
表-1 主要植物油脂原料処理量 ( $\mathrm{t} /$ 年) （）内油生産量 $(t /$ 年)

\begin{tabular}{|c|c|c|c|c|}
\hline 原 料 & 年 & 昭和 35 年 & 昭和 38 年 & 昭和 39 年 \\
\hline 大 & 豆 & $\begin{array}{c}940,556 \\
(167,847)\end{array}$ & $\begin{array}{c}1,191,829 \\
(211,065)\end{array}$ & $\begin{array}{c}1,244,774 \\
(223,194)\end{array}$ \\
\hline ナ & ネ & $\begin{array}{l}353,126 \\
(98,163)\end{array}$ & $\begin{array}{l}162,691 \\
(60,871)\end{array}$ & $\begin{array}{l}180,054 \\
(62,791)\end{array}$ \\
\hline 又 & 力 & $\begin{array}{l}233,562 \\
(39,727)\end{array}$ & $\begin{array}{l}277,683 \\
(49,724)\end{array}$ & $\begin{array}{l}357,146 \\
(63,219)\end{array}$ \\
\hline 綿 & 実 & $\begin{array}{c}93,172 \\
(18,051)\end{array}$ & $\begin{array}{l}166,826 \\
(30,717)\end{array}$ & $\begin{array}{l}199,463 \\
(36,161)\end{array}$ \\
\hline サフラワ & - & $\begin{array}{c}88,206 \\
(31,455)\end{array}$ & $\begin{array}{l}159,330 \\
(55,496)\end{array}$ & $\begin{array}{l}220,326 \\
(80,404)\end{array}$ \\
\hline 广 & $=$ & $\begin{array}{l}104,006 \\
(38,363)\end{array}$ & $\begin{array}{c}95,778 \\
(35,552)\end{array}$ & $\begin{array}{c}98,540 \\
(37,099)\end{array}$ \\
\hline ב & ラ & $\begin{array}{c}88,237 \\
(55,989)\end{array}$ & $\begin{array}{l}105,401 \\
(67,765)\end{array}$ & $\begin{array}{c}92,684 \\
(59,869)\end{array}$ \\
\hline パー - & 核 & $\begin{array}{c}25,808 \\
(12,912)\end{array}$ & $\begin{array}{c}26,082 \\
(12,790)\end{array}$ & $\begin{array}{c}24,031 \\
(11,711)\end{array}$ \\
\hline$=゙$ & $\rightarrow$ & $\begin{array}{l}10,738 \\
(4,894)\end{array}$ & $\begin{array}{l}16,321 \\
(7,001)\end{array}$ & $\begin{array}{l}19,781 \\
(8,906)\end{array}$ \\
\hline ヒ & シ & $\begin{array}{c}30,977 \\
(13,520)\end{array}$ & $\begin{array}{c}35,764 \\
(16,164)\end{array}$ & $\begin{array}{c}34,279 \\
(14,903)\end{array}$ \\
\hline ヒマワ & リ & $\begin{array}{l}17,470 \\
(6,032)\end{array}$ & $\begin{array}{l}12,261 \\
(8,992)\end{array}$ & $\begin{array}{c}809 \\
(333)\end{array}$ \\
\hline
\end{tabular}

表-2 主要植物油脂原料の含油量および形状

\begin{tabular}{|c|c|c|c|}
\hline 種 & 類 & 含油量 $(w t \%)$ & 状 \\
\hline 大 & 豆 & $18-20$ & 球 （代表径 $8-10 \mathrm{~m} / \mathrm{m}$ ) \\
\hline ナ & ネ & $22-50$ & 平ダ(榙)球(代表径 $2-3 \mathrm{~m} / \mathrm{m}$ ) \\
\hline 又 & 力 & $18-21$ & 粉 末 \\
\hline 綿 & 実 & $\left\{\begin{array}{l}16-35 \text { (種) } \\
34-39 \text { (核) }\end{array}\right.$ & 球（代表径 $3-5 \mathrm{~m} / \mathrm{m}$ ) \\
\hline サフラワーシ & シード & $34-35$ & 米穀状（米穀大） \\
\hline プ & ラ & 65-75(乾果肉) & \\
\hline パーム & 公核 & 46-57(乾核) & \\
\hline$ア \quad \checkmark$ & $=$ & $28-44$ & \\
\hline ゴ & $\checkmark$ & $35-56$ & 平ダ球（代表径 $2 \mathrm{~m} / \mathrm{m}$ ) \\
\hline 力 ポッ & ク & $20-25$ & 球（代表径 8-10 mm) \\
\hline
\end{tabular}

の難易に重大な影響を有している。前処理の方法は，油 脂原料の性状によりまた抽出操作の種類により異なるが 一般的には図-1 および図-2 に示す工程により行なわ れる。図-1 に示すものは直接溶剤抽出の前処理を示し 図-2 は圧抽法につき示したものである。困に従い各操 作の説明をする。

\section{$2 \cdot 1 \cdot 1$ 精 選 (cleaning)}

油脂原料は多かれ少なかれキョウ雑物を含んでいる。 キョウ雑物の種類は茥, 葉, サヤ(英), 土砂, チリ(塵), 異種子，その他鉄片などである。これらのキョウ雑物の 混入は製品油および抽出カスの品質に大きな影響を及ぼ すと同時に鉄片,土砂,チリなどの混入は粉砕, ロール,輸 送機および抽出機などの寿命を左右するとともに連続操 作の難易に影響するので充分除去しなければならない。
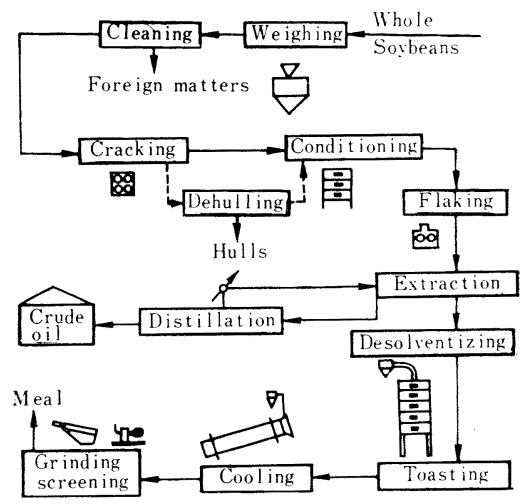

Direct solvent extraction (cont inuous)

図-1

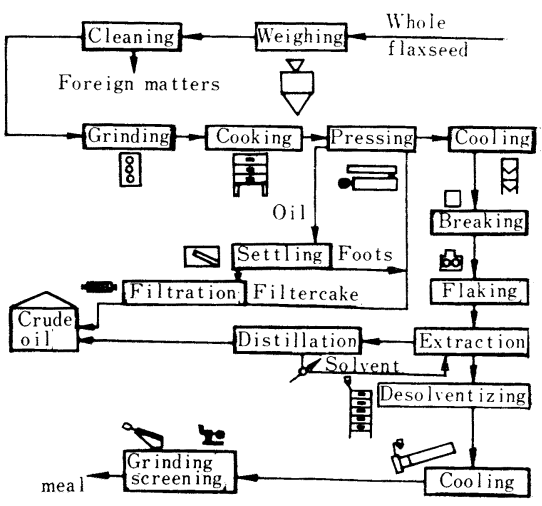

Cont inuous mechanical press and solvent extraction (prepress process)

図-2

一般に鉄片などの金属類は，マグネチックセパレーター により除去され, 茥, 葉, サヤ, 土砂, ジンアイ(塵埃) その他のキョウ雑物は, フルイ分けと風選により除かれ る。フルイ分けは通常振動フルイで行なわれるが, 最近 のものはフルイに風選設備を兼備し, これらのキョウ雑 物除去も同時に行なうものが多い。また有害種子が混入 している場合には, ディスクセパレーターを使用する場 合もある。たとえば大豆原料に混入している朝顔の種子 は，ディスクセパレーターで除去されることが多い。

$2 \cdot 1 \cdot 2$ 脱皮（款）(dehulling)

表-3 に示すように, 多くの種子のカラ (款) は, 普通 含油量が $1 \%$ 以下であるので, 種子中でカラの占める割 合の多い, 綿実, ヒマワリ, ヒマシ, 落花生などは, 脱 皮を行なうことが多い。これは含油量の少ない皮を除か ずに抽出すれば，皮に油が吸収され，採油率が落ちたり カサ張るため処理能力が低下したり, また設備の摩耗な どの不利があるためである。ただしアマ, エゴマ, ナタ ネ,ゴマなどの小さな種子の脱皮は一般に行なわない。

これらの原料は，それぞれ特定の脱皮 (殼) 機が使用 されるが, 綿実, ヒマワリ, 落花生のような可トウ 
表-3 各種種子の皮と実の割合ならびに油の分布

\begin{tabular}{|c|c|c|c|c|c|}
\hline \multirow{2}{*}{ 種子名 } & \multirow{2}{*}{ 实 } & \multirow{2}{*}{$\begin{array}{c}\text { 皮 } \\
\text { (款) }\end{array}$} & \multicolumn{2}{|c|}{ 含 油 } & 率 \\
\hline & & & 全種子 & 実 & 皮 \\
\hline \multicolumn{6}{|l|}{ （1）通常脱皮するもの } \\
\hline 油シュロ (Oil palm) & 25 & 75 & - & 48 & - \\
\hline ババスウ（Babasu） & 9 & 91 & - & 67 & - \\
\hline 油キリ (Tung nut) & 60 & 40 & 30 & 50 & - \\
\hline カカオ (Cacao beans) & 88 & 12 & 50 & - & - \\
\hline ヒマ (Castor beans) & $70 \sim 80$ & $20 \sim 30$ & $40 \sim 50$ & - & - \\
\hline 綿実 (Cotton seed) & 62 & 38 & 19 & 30 & $1 \sim 2$ \\
\hline 落花生（Peanut） & 75 & 25 & 38 & 50 & $0.5 \sim 1$ \\
\hline ヒマワリ (Sunflower) & \multicolumn{5}{|c|}{$45 \sim 60|40 \sim 55| 22 \sim 3636 \sim 55$} \\
\hline カポック (Kapok) & 60 & 40 & $20 \sim 25$ & 40 & - \\
\hline サフラワー(Sufflower) & 50 & 50 & $28 \sim 335$ & $5 \sim 65$ & $1.5 \sim 2$ \\
\hline \multicolumn{6}{|l|}{ （2）通常脱皮しないもの } \\
\hline 大 豆 (Soy bean) & 93 & 7 & 18 & - & 0.6 \\
\hline$\checkmark \vee($ Flax seed) & 57 & 43 & - & 58 & 22 \\
\hline フ サ (Hemp seed) & 62 & 38 & 31 & - & - \\
\hline ナタネ（Rape seed） & 82 & 18 & 42 & - & - \\
\hline
\end{tabular}

(暁)性の皮を持つ中程度の大きさの種子には，円板型脱 皮機 (disc huller) または棒型脱皮機 (bar-huller) が, 用いられる。脱皮機にかける場合，種子は適度の水分を 含むことが必要で水分が多ければ脱皮機に種子が詰り， らまく砕けず，乾燥し過ぎているときは，微粉末が極端 に多くなり, 後の操作の作業性を悪くし, 能力低下をき たしやすい。脱皮後の実と皮（殼）の分離は，振動フル イと風選により行なわれる。大豆については，外皮の部 分は $7 \%$ 前後で小さく, また油の吸収性も少ないため, 脱皮はほとんど行なわれなかったが，高タンパク脱脂大 豆の需要が高まり，また脱皮による油およびレシチンの 品質改善効果が認められ，抽出力スの用途によっては， 脱皮される場合も多い。大豆の脱皮は，粗砕を行ならこ とにより皮を実からはぎ，アスピレーターで皮を分離す るのが普通である。サフラワーは 表-3 に示すようにカ ラの占める割合が $50 \%$ もありカラの油分も 1.5 2.0\% と低いし，外皮の除去法いかんでは，脱脂大豆に匹敵す る良質のカスが得られるので, 脱皮設備の発達は大いに 注目され，アメリカのパシフィック・ヴェジタブルオイ ル社が積極的に開発を行なっているようだ。

$2 \cdot 1 \cdot 3$ 粗砕 (cracking), 粉砕 (crushing) および圧 扁 (flaking)

圧搾法, 溶剤抽出法いずれの場合でも, 抽出原料の細 胞膜をできるだけ破壊し, さらには破壊した細胞中の油 が流出しやすいようにすることが望ましい。圧搾法の場 合はこれを粉砕, 圧扁, 蒸煮で行なっている。溶剤抽出 法の場合も圧搾法と同じような操作で行なっているが, 溶剤抽出法の場合にはさらに溶剤と油の種子中での拡散 距離を短縮し抽出速度を増加するため, またフレーク層 中のミセラの貫流特性をよくすることが必要のため, 微
粉末の少ない薄いフレークを作ることが必要である。

Coat および Wingard ${ }^{7}$ の研究によれば，フレークの 残油率 $1 \%$ (ソルベントを含まず, 乾規準とする)に達 するまでの抽出時間はつぎの関係式に従う。

$$
\begin{aligned}
& T=K D^{r} \\
& T ; \text { 抽出時間 } \\
& D ; \text { フレーク愿み } \\
& K \text {; 原料に固有の常数 } \\
& n ; \text { 原料に固有の常数(大豆フレークにつ:ては2.3〜2.5) }
\end{aligned}
$$

上式のように，フレーク厚みを薄くすれば，抽出時間 を短くでき，抽出機も比較的小型にすることができるの で，薄いフレーク厚みが好ましいが，実操作では，圧扁 機の性能, 抽出力スの用途, フレークの機械的強度, フ レーク層中のミセラの貫流特性などを考え最適の厚みを 決めるとともに, できるだけ均一な厚みのフレークを作 ることが大切である。

大豆の浴剤抽出では丸大豆をクラッシングロールで粗 砕したのち，圧扁をするが，王扁の前にコンディショニ ングを行ない。原料を温度 $71 \sim 76^{\circ} \mathrm{C}$, 水分 $10 \sim 11 \%$ に 調整するのが普通である。压扁の前に, 加温するのは圧 扁をしやすくするためであり，水分調整をするのは薄く 微粉末の少ない良質のフレークを得るためには適当な水 分が必要で, もし乾燥し過ぎた種子ではうまくフレーク にならず微粉末が多くなり抽出操作に悪影響を持つから である。各社の抽出機の場合, いずれも原料中の微粉末 の含量を規定しているのが普通である。

フレークの厚みについてはアメリカでは一般に $0.2 \sim$ $0.3 \mathrm{~mm}$ ，わが国では通常 $0.3 \mathrm{~mm}$ 前後が使用されてい るが：ミソ，ショウ油などの醸造用原料として，抽出力 スを使用する場合には $0.5 \mathrm{~mm}$ 以上にすることもあると いう。

抽出装置の大型化に伴い，クラッキングロール，フレ 一キングロールの発達も著しく最近では一台で 300-400 $\mathrm{t} /$ 日 の処理能力を有するものがあり厚みのバラツキも $\pm 0.05 \mathrm{~mm}$ におさえることが可能といわれる。

コプラ，パーム核などの場合にはまずハンマーミル， アトリッションミルなどで粉砕を行ない $5 \sim 10 \mathrm{~mm}$ とし たのち,さらに粉砕ロールにかけ $2 \sim 3 \mathrm{~mm}$ とし熱処理, 乾燥後, エキスペラーにかけ搾油する。搾油後のプレス ケーキを溶剂抽出する場合には，プレスケーキをブレー カーにかけ粗砕したのちフレーキングロールにかけフレ 一クにしたものを抽出にかけるのが普通であるが，フレ ークにしないで粗砕したまま抽出にかける場合もある。 フレークにする場合には微粉末の生成をできるだけ抑え ることが必要で，フレーキングの前に，水分調整をする ことが多い。

$2 \cdot 1 \cdot 4$ 熱処理 (heat treating)

溶剤抽出では $2 \cdot 3$ の例外を除き蒸煮を行なわないが, 
フレーキングロールの負荷を軽くすることおよび良好な フレークを得る目的のため加温と水分の調整を行なら。 これらの操作をコンディショニングまたはテンパリング と呼び，スチームジャケット付の横(タテ)型円筒かくは ん器, または,ロータリーキルン型の装置で行なうのが普 通である。綿実その他高含油種子では溶剤抽出のときに も蒸募の行なわれることがある(cooked meat process)。 この場合には, まず $0.25 \mathrm{~mm}$ くらいの大きさに粉砕し たのち温度 $104 \sim 110^{\circ} \mathrm{C}$, 湿度 $15 \sim 25 \%$ で 30 45 min 蒸募し, 仕上げ湿度は 10〜14\% とする。これをさらに 蒸発冷却により表面を乾燥し, 多孔性の粒子として(こ の操作を crisping と称する) 溶剤抽出を行なうといわ れる。

\section{$2 \cdot 1.5$ 乾 燥 (drying)}

大豆フレークの乾燥は, アメリカでは一般に行なわれ ない。フレーキングの前のコンディショニングで水分を 10 11\%に調整すれば抽出に関し，問題はないからであ る。しかしわが国では水溶性タンパク含量の高い脱脂大 豆フレークを製造するなどの特殊性のため大豆フレーク を乾燥することがある。この場合, 乾燥後のフレーク水 分は 8 10\% で, 乾燥機には通気式バンド乾燥機の使わ れることが多い。

ヌカの場合は抽出前に乾燥が行なわれるのが普通であ る。これはヌカが微粉末で, 溶剤抽出にかける前に, 原 料加熱が必要で, 同時に乾燥することにより, 溶剤のヌ 力層中への浸透を促進し，ミセラの貫流特性をよくする ことができるからである。ヌカの乾燥には通常ジャケッ 卜付横型円筒かくはん乾燥機が使用されている。

\section{2 抽出工程 5 ) 10)}

抽出工程に湴通, 抽出 (extraction), ミセラ蒸留 (miscella distillation), 抽出カスの脱溶剤 (meal desolventizing), 溶剤回収 (solvent recovery) の四つの 工程が含まれる (図-3 参照)。連続抽出の場合はこれら を全体として一つのプロセスユニットにまとめ, 原単位 の低下, 設置面積の縮小, 運転の簡素化などを計ってい る。この 4 工程につき順に説明する。

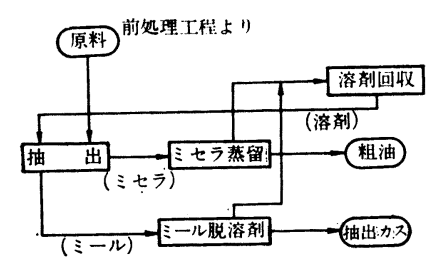

図-3 抽出工程のブロックダイヤグラム

$2 \cdot 2 \cdot 1$ 抽 出 (extraction)

抽出に関する基磷的事項については, 多くの報文 ${ }^{5), 9)}$ があるので, ここでははぶき, 主要連続抽出機について 述べる。主要連続抽出機を型式別に分類すると，表-4 のようである。
裁-4 植物種子連続抽出装置一臨表

\begin{tabular}{|c|c|c|c|}
\hline \multirow[t]{6}{*}{ 貫流式 } & \multirow[t]{3}{*}{ 型スケット } & 㹂 & $\begin{array}{l}\text { Bollman (独) } \\
\text { French Oil Mill Machinery Co.(米) }\end{array}$ \\
\hline & & 横 型 & French Oil Mill (*) \\
\hline & & 角 型 & French Oil Mill (米) \\
\hline & \multirow[t]{2}{*}{ 七几式 } & 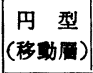 & $\begin{array}{l}\text { Karussell (Extraktionstechnik 独) } \\
\text { Rotocel (Blaw Knox } * \text { ) }\end{array}$ \\
\hline & & \begin{tabular}{|l|} 
蹎定裂) \\
\end{tabular} & French Oil Mill (*) \\
\hline & $\begin{array}{l}\text { ベルトコン } \\
\text { ベア型 }\end{array}$ & & $\begin{array}{l}\text { De Smet (ペルギー) } \\
\text { Lurgi (独) }\end{array}$ \\
\hline \multirow[t]{5}{*}{ 浸セキ式 } & スクリグテ & & \begin{tabular}{|l|} 
Hildebrandt (独) \\
Detrex (米) \\
Crown (米) \\
跉木式 (日) \\
\end{tabular} \\
\hline & 塔 式 & & $\begin{array}{l}\text { Allis Chalmer (*) } \\
\text { V.D. Anderson (*) } \\
\text { Bonotto (*) }\end{array}$ \\
\hline & $\begin{array}{l}\text { 岿スケット } \\
\end{array}$ & & 石 井 (日) \\
\hline & 遠心分離式 & & Sherwin-Williams \\
\hline & セn 式 & & Kennedy (米) \\
\hline \multirow{3}{*}{ 贯流清 } & $\begin{array}{l}\text { 分スケット } \\
\text { 式 }\end{array}$ & & Miag（独） \\
\hline & 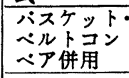 & & 千代田L型（日） \\
\hline & 口過抽出法 & & Filtrex (Wurster \& Sanger, 米) \\
\hline
\end{tabular}

表-4に示すように,連続抽出機は貫流式 (percolation type), 浸セキ型 (immersion type), および両者併用式 の三つに大別される。ここで貫流式といらのは spraypercolation の意味で固体層の上方から散布された溶剤 が固体層中を重力で流下するものである。浸セキ式とは 固体が溶剤中に浸セキするもので, 両者併用式は貫流式 と浸セキ式おのおのの久点を補い長所を生かすため両型 式を組み合わせたものである。貫流式と浸セキ式の優劣 を示すと表-5 のとおりであるが最近米国においては, 浸セキ式は他の 2 者とくに貫流式に取って替わられつつ あり,わが国のおむな連続抽出装置も, ほとんど貫流式 である。これは, 表-5 に示される浸セキ式の, 抽出効 率がよく, コンパクトであるという利点も, 貫流式のミ セラのロ過が容易であること, 溶剤回収工程のニーティ

衰-5 貫流式と浸セキ式連続抽出装置の比較

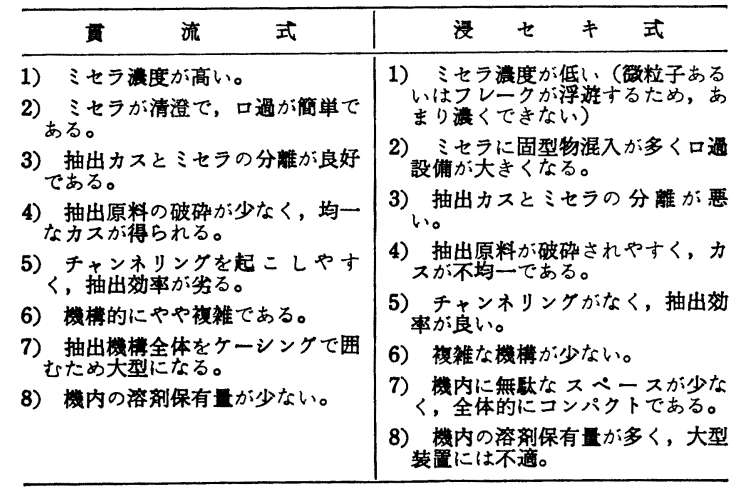




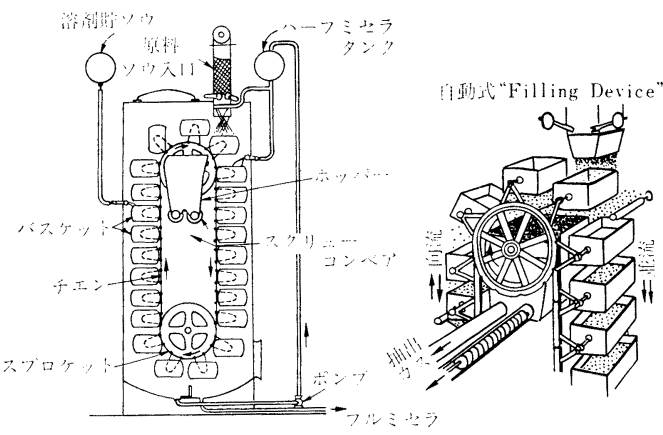

図-4 Bollmann 抽出機

リティー消費量が少ないという長所に加えて, 多段 向流連続装置の出現により, 従来不利だった抽出効 率の点も，溶剤を循環することにより浸セキ式に近 づけられ，したがって装置の大きさも減小したこと により克服されたためと思われる。

貫流式抽出機で最も古く代表的なものはドイツの Hansa-Müle Co. が 1919 年に特許を取って発達し たタテ型バスケット式の Bollmann 抽出機(図-4 参 照) で処理能力が大きく, アメリカ内の数社により 採用されている。これに類する装置を多くのメーカ 一が各種の工夫をこらして製作しているが，アメリ カにおいてはFrench Oil Mill Machinery Co.の ものが代表的でありタテ型の外角型(中能力), 水平 型(小能力)などもある。タテ型バスケット式抽出機 は装置の高さが大で最近の貫流式抽出器はほとんど 横型となった。Blaw Knox 社の Rotocel 抽出機 ${ }^{11}$ (図-5 参照) はバスケット型に比しコンパクトで高 性能を有し，アメリカでは大豆 $1,800 \mathrm{t} /$ 日の大処理

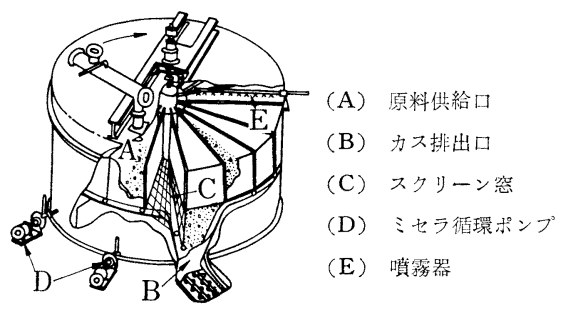

図-5 Rotocel 抽出機

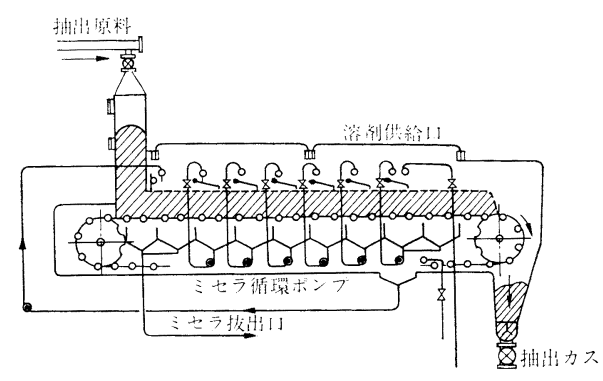

図-6 De Smet 抽出機
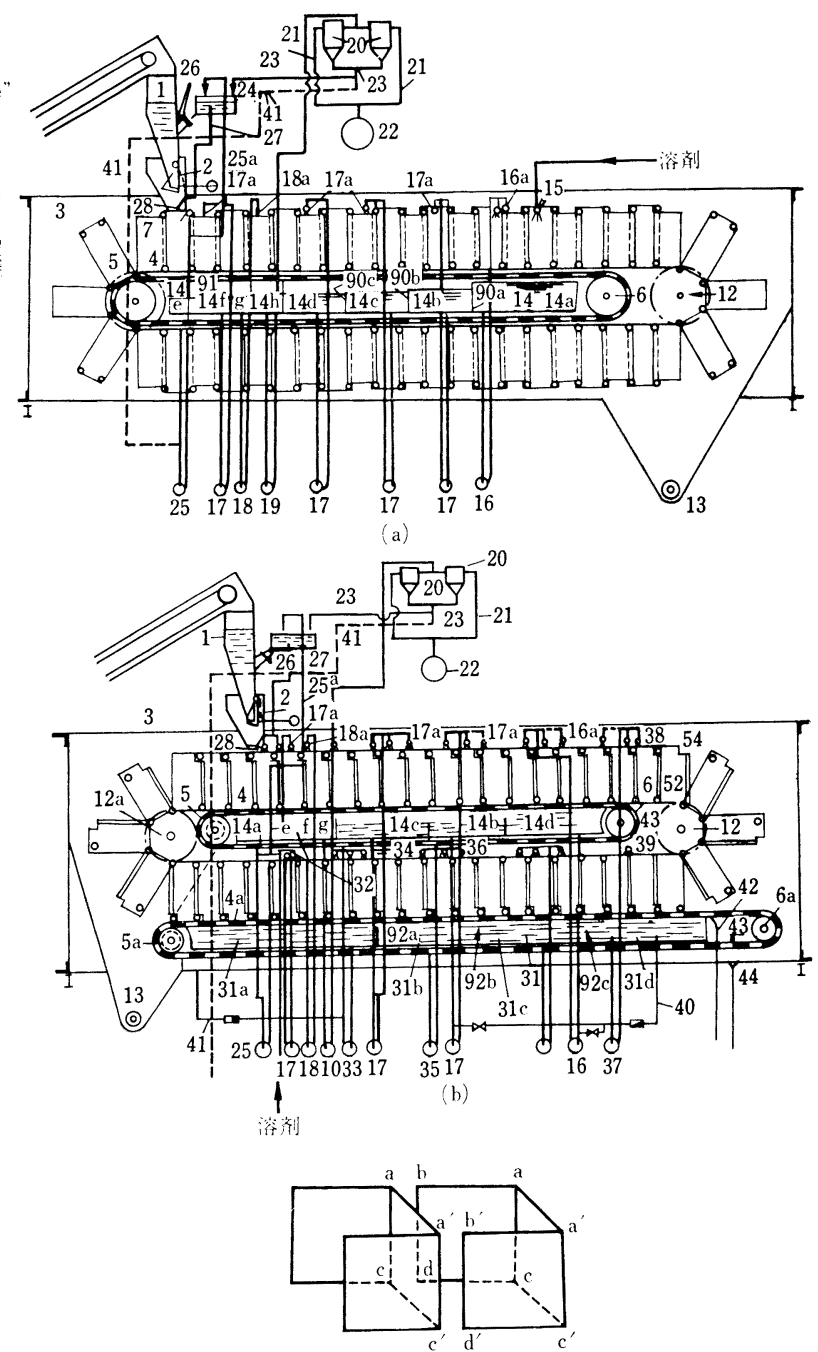

図-7 Lurgi 式抽出機 (a ) 単式, (b ) 複式, (c) セル 能力を有するものも稼動しているとのことで, わが国で は三菱化工機 (株) が取扱い数社で稼動している。De Smet 抽出機 (図-6) は 1945 年ベルギーの Jean Albert De Smet の発明による機構的に簡単な水平型ベルトコ ンベヤー式連抽機でヨーロッパなどで多く採用されてい る。わが国でも 2 3 社で稼動中である。ドイツ Lurgi 社の設計による連続抽出機 ${ }^{12)}$ (図-7 参照) は比較的新し いもので De Smet 抽出機の改良型と見なしうるベルト 型に間仕切りを入れた型式のものであるが単式と複式が あり複式ではコンベヤーが上下 2 段あり上段で抽出を終 った原料は下段に落下しフレーク層を崩し, ミセラの不 均一接触を防ぎさらに反対方向へ移動しつつ抽出され る。間仕切りは上下段とも巧みに兼用できる構造となっ ている。Lurgi 式も De Smet 式もアメリカではあまり 使用されていないがわが国ではかなり注目され $400 \mathrm{t} /$ 日 くらいまでのものが数社で採用され稼動している。アメ 


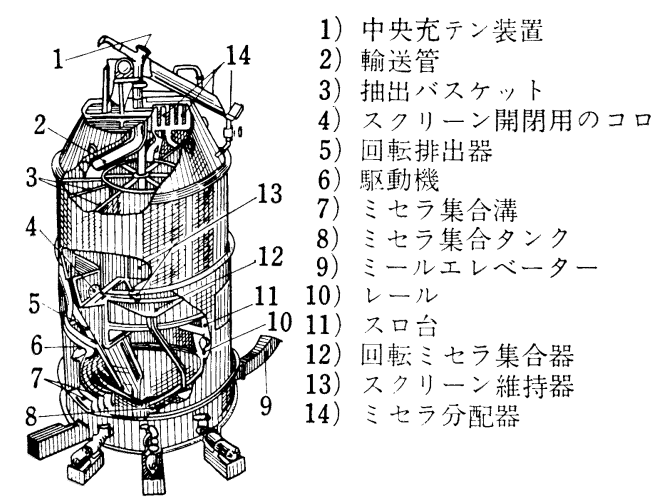

図-8 Stationary basket extractor

リカ French Oil Mill Machinery Co. の stationary basket extractor ${ }^{13)}$ (図-8 参照) は固定層式の連続抽出 機で新しい型式のものである。この抽出機は外観は Rotocel 型によく類似しているが原理的には異なり， Rotocel 型が移動層式であるのにこれは固定層式でバス ケットは固定され回転しないかわりに各バスケットに対 匛した外周部が回転し順次原料の供給, ミセラの散布, 抽出終了したミールの排出を連続向流に行なえるように なっている。抽出機が大型となったとき，多量の固体を 移動する必要なく有利とのことであるが，構造はかなり 複雑である。このほかドイツ Extechnik 社のカローザ ル抽出機 ${ }^{14)}$ (これについては後述する)もかなり新しい。 この抽出機も Rotocel 型に類似しているが Rotocel 型 では底部のスクリーンベッドが各セルに固定しセルとと もに回転するのに, この抽出機では底部のスクリーンベ ッドは抽出機本体に固定し回転せず原料は押されてこの スクリーンベッドの上を滑りながら抽出される構造とな っているので, スクリーンベッドは常に原料により掃除 され，絶対に目詰まりを起こさず，きわめてよいミセラ の振りが得られるという。これらの貫流式抽出機は大豆 抽出を主目的としたものが多いが大豆のほか綿実, アマ ニ,ナタネ,サフラワーなどの高含油種子のプレスケーキ の抽出にも広く使用される。ただし微粉末原料または微 粉末を多く含む原料については, 原料層中のミセラの流 れが悪く, チャンネリングなども生じやすいので原料を ペレット化し抽出にかける場合が多い。わが国にとり重 要な国内産の油脂資源であるヌカは微粉末で含油量も少 なくまた小規模であったので従前は浸セキ式(鈴木式, 赤 松式など)抽出機使用が多かったが, 日本精米(株)では貫 流式のデスメット改良型抽出機を使用し微粉末のまま連 続溶剤抽出を効率よく行なっている。この抽出機は現在 2 社で稼動中で近い将来また 2 基建設されるようである。

浸セキ式抽出機の代表とされる Hilderandt 抽出機 (図-9 参照) は Bollmann 抽出機と同じくドイッで発 明されたものでドイツおよびアメリカで主として大豆抽

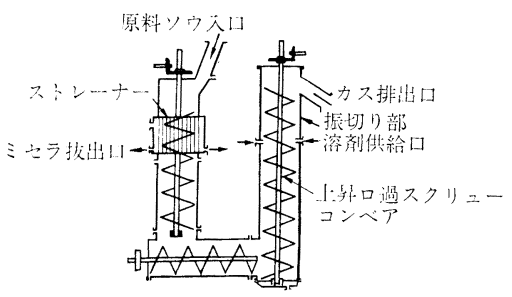

図-9 Hildebrandt 抽出機

出用に, ヨーロッパでは他の原料にも使用されている。 Allis-Chalmers Manufacturing Co. およびV.D. Anderson Co. の vertical single tube gravity type extrac. tor はアメリカで発明された浸セキ式の代表的なむので いずれも似た形式であるが，V.D. Anderson Co. のも のは溶剤回収も含めコンパクトな屋外設置である。

また M. Bonotto の設計になる Bonotto 抽出機 (図-10 参照) は同様の型式であるがこの変形である modified Bonotto 抽出機 (図-11 参照) は前記 2 者で は原料が回転羽根でかくはんされるのに対し原料を支え ているトレーが回転し原料は固定バッフルにより回転が さまたげられトレーのスロットから重力で落ちて行く構 造となっている。

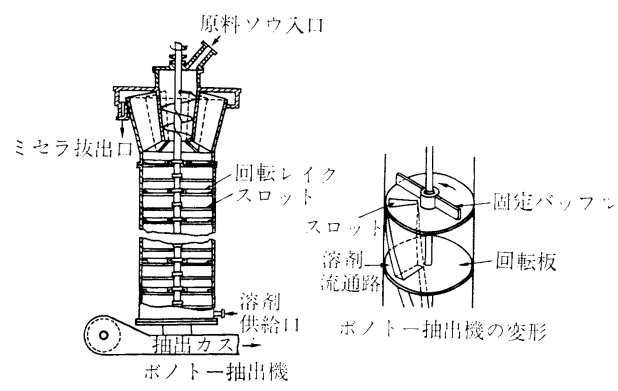

図-10 Bonotto 抽出機

Kennedy 抽出機（図-11 参照）は各種の植物種子や 薬物など一般に溶剤抽出がむずかしいといわれる原料の 抽出に用いられる。このほか水平バスケット型の浸セキ 式抽出機として石井式連続抽出機, スクリューコンベヤ 一型として Detrex 抽出機, 鈴木式連続抽出機（いずれ も小能力向）などがある。

貫流-浸セキ併用式としてはドイツ Miag Mühlenban
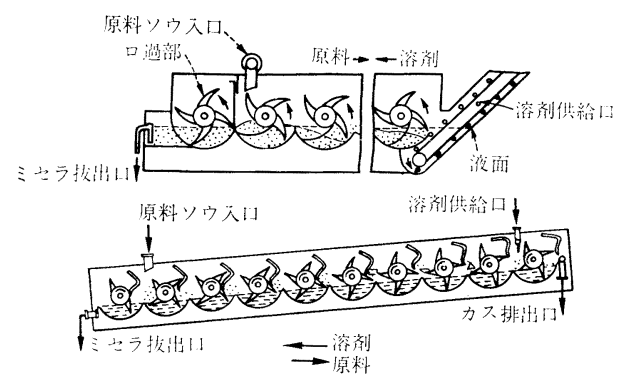

図-11 Kennedy 抽出機 


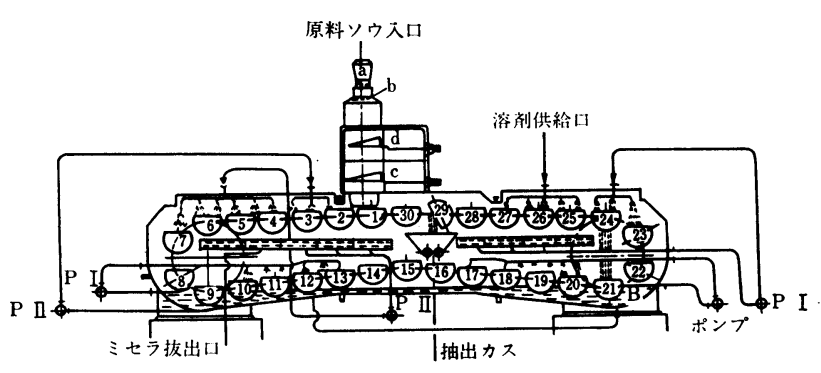

図-12 MIAG バスケットバンド式抽出機 und Industrie G.m.b.H のバスケットバンド式抽出 機 (図-12 参照)，アメリカの Southern Regional Research Laboratory, Agricultural Research Service, U.S.O.A. が開発した filtration extraction system ${ }^{15)}$, 16)，わが国の千代田式L型連続抽出機などがある。

$2 \cdot 2 \cdot 2$ ミセラ蒸留 (miscella distillation)

ミセラ蒸留装置はミセラから溶剤を加熱蒸発せしめ油 と溶剤に分離する装置であるが，ここで重要なことは， （1）油の品質劣化をさせないこと，(2) 熱利用を効率的 に行ない原単位を低下させることであろう。第一の油の 品質劣化を防止する方法としては蒸発およびストリッピ ングの工程を减圧下で行ない油温を $85^{\circ} \mathrm{C}$ 以下におさえ 達しているのが普通である。また第二の目的の実現のた めにはミセラ蒸発につき多重効用式の方法 (図-13 参照) を使用するか, カス脱溶剤系からくるベーパーの廃熱を

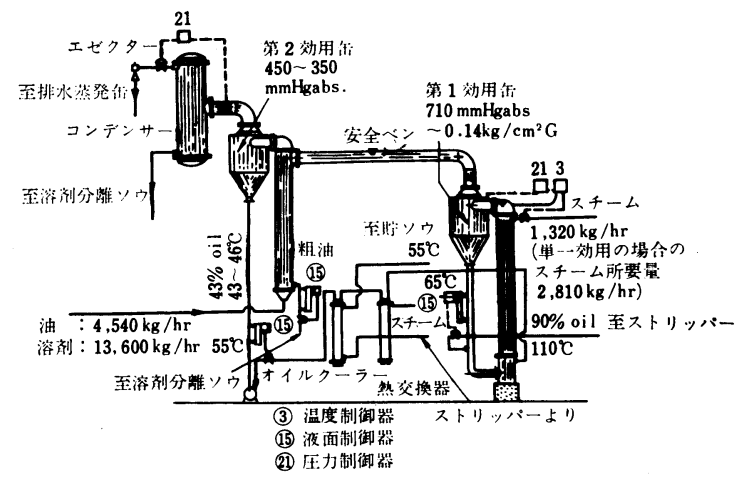

図-13 ミセラ蒸発装置-二重効用式

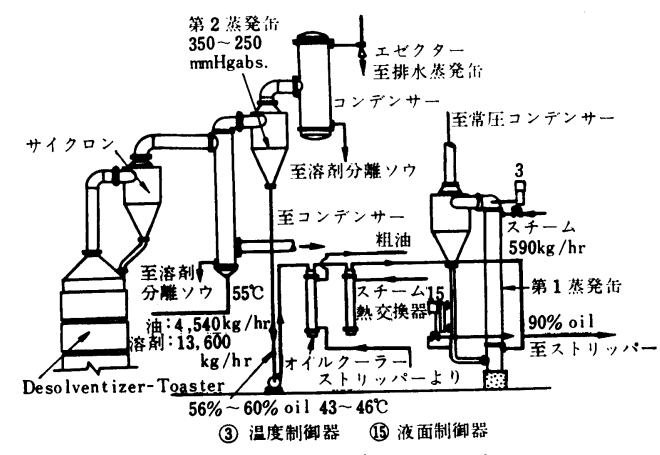

図-14 ミセラ蒸発装置-dual evaporation system
利用する方法 (図-14 参照) が普通である。ブロー ノックス社の設計には前者の方法が多くルルギ, フ レンチなどの設計には後者を使用している場合が多 以。

$2 \cdot 2 \cdot 3$ 抽出カスの脱溶剂 (meal desolventizing) 表-1に示したように大豆の処理容量の急増に伴 いカス脱溶剤設備の重要度が再認識される。

大豆原料の $80 \%$ が脱脂大豆カスでタンパク質含 量が半分にも達することを思えば当然だろう。

現在連抽カスの脱溶阂設備にはつぎの三とおりの 方法が広く行なわれている。

最も古くかつ慣例的な方法はシュネッケンと呼ばれる スチームジャケット付コンベヤーチューブにより脱溶剤 する方法である。第二の方式はブローノックスおよびア リスシャルマー社が用いている過熱溶剤ベーパー脱溶剤 法 (solvent vapor desolventizing system) ${ }^{17}$ ) でる。 第三の方法は一般に D.T. と呼ばれる装膡で生蒸気を吹 き込み脱溶剤すると同時にトースト処理 (toasting) も あわせ行なう水蒸気脱溶剂法 ${ }^{18)}$ （steam-desolventizing system）である。

第一のシュネッケン型は内部にパドルまたはリボンュ ンベャーなどのカクハン型輸送機を有するジャケット付 横型円筒乾燥機で通常数段の直列組合せ（図-15 参照） で使用され大部分の溶剤はジャケット加熱で脱溶剂され 脱溶剤の最終段階で生蒸気を吹き込み小量の残溶剤を除 去するもので, ルルギ, デスメット型の抽出装置にはこ の型が多い。第二の過熱溶剤ベーパー脱溶剤法 （図-16

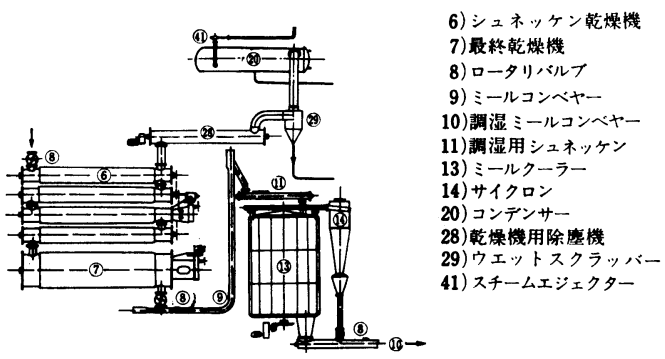

図-15 シュネッケン脱溶绪機

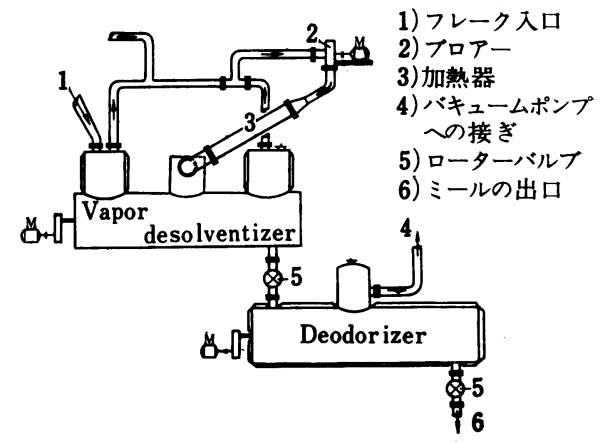

図-16 過熱溶绪ベーパー脱溶绪法 
参照）とは過熱溶剤蒸気を循環しフレーク中の溶剤にそ の潜熱を与えこれを蒸発させる方式である。この方法は 低温度で脱溶凨できるのでフレークの変質を最小に留め られる。この vapor-desolventizer 化付随する deodorizer はカスの目的により真空あるいは常圧いずれの方 式にもすることができるが，とくに脱脂大豆の場合 vapor desolventizer-vacuum deodorizer 方式により処 理されたフレークはタンパク質の熱変性がほとんどない とされており高含量の水溶性タンパク脱脂大豆を目的と するような場合有効のようである。

第三の steam-desolventizing system ${ }^{18)}$ というのは D.T. 方式と呼ばれるスタック型の desolventizer toaster（図-17 参照）を使い直接スチームを吹き込み脱溶 剤すると同時にトーストする方法である。この方法によ

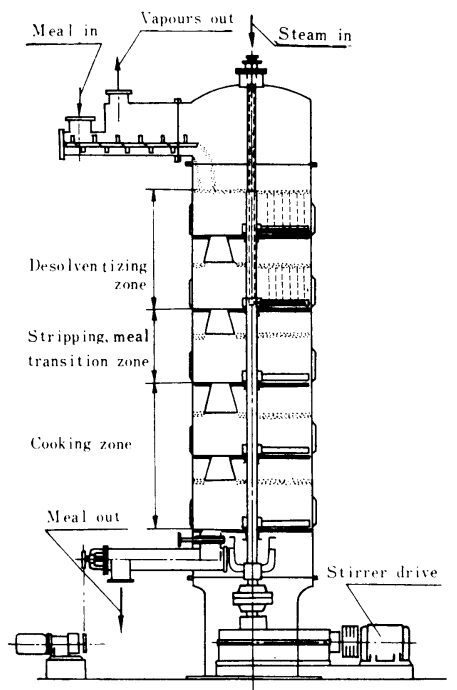

図-17 Desolventizer toaster

るとソルベントでぬれたフレークは吹き込まれた生蒸気 と接触し溶剤とスチームは爆発的に入れ換わり, フレー クは脱溶剂と同時に凝縮した水分で均一に加湿され，水 分 18 20\% となりさらに加熱保持され脱脂大豆中の夕 ンパク質はきわめて均一かつ円滑に変性されるという。 またこの装置だと溶剤蒸気が上部へ抜けて回収装置へ行 く前に溶㓮で湿潤しているフレーク中を通過するので吹 き込んだ生蒸気が有効に使用されると同時にガス洗浄が 行なわれ簡単な粉末洗浄サイクロンを通すだけでベーパ 一をミ七ラ蒸発器の熱源に回収できる。一方フレーク中 の有害酵素を失活させ脱脂大豆の消化性や栄養価を改善 することができるので飼料用脱脂大豆の需要増大に伴い この方法の採用が増加しょう。現在わが国ではこの型式 の脱溶剤設備が 2 3 台稼動中である。このほか flash desolventizer ${ }^{19}$ が報告されているがタンパク質の変性に 関しては第二の方法と同程度のようである。

$2 \cdot 2 \cdot 4$ 溶剂回収 (solvent recovery)
原料フレークに伴われてまたはその他の箇所から連続 抽出装置系内に入った空気は溶剤を伴っているので, で きるだけコンデンサー, クーラーで冷し，随伴したソル ベントを落したのち, 溶剤回収装置に通し残余の溶剂を 回収する。この溶剤回収法には, 吸収法, 吸着法, 冷凍 法の 3 法があるが，最近の連続抽出装置では，冷凍法， 吸収法の使用が多い。

冷凍法というのは溶剤を伴った空気を直接または間接 に冷凍しできるだけ溶剤を回収する方法でルルギ社の設 計ではブラインによる直接冷却が多く, ブローノックス 社でも古いものは間接冷凍が使用されていた。吸収法は 特殊な吸収液を循環し空気に伴われた溶剂を吸収塔で吸 収しストリッパーで追い出し回収するものであるが, 最 近すぐれた吸収液の発見により，吸収法が多くなりつつ あるようである。

\section{3 カローザル抽出装置 (Carrousel extraction plant)}

カローザル抽出装置は，表-4 に示したように貫流式 (percolation type) のセル型円型の抽出機を主体とする もので, 抽出機はロートセル型 (Rotocel 型) と同様, セルが水平面上を回転するため構造簡単にしてきわめて コンパクトである。またこの抽出機ではスクリーンベッ ドは回転せず固定しておりセル中の原料はスクリーンベ ッドの上を入口より出口まで滑って行きスクリーンベッ ドは常に原料で自浄される構造となっており, 抽出後の 原料排出も，スクリーンベッドに設けられた簡単な落下 口があり, その落下口から連続的に排出されるので, 稼 動部分がきわめて少ない。このことは, 大容量にして高 性能抽出機を約束しており, 出現後まだ日新しいにかか わらず，すでに欧州で $1,200 \mathrm{t} /$ 日 の大豆用抽出装置を設 計中とのことである。

カローザル抽出装置はドイツのエキステクニク社 $\mathrm{W}$. Depmerの発明によるもので低残油分, 高濃度自浄ミ セラに特徵を持つカローザル抽出機を主体とし, 溶剂損 失が少なく飼料用脱脂力ス製造に最適である, 米国セン トラルソーヤ社の desolventizer toaster を含む一連の 装置で大豆を初め, 綿実, ナタネ, サフラワーなどのエ キスペラーケーキの抽出用に広く使用されている。開発 後まだ新しいが, すでに欧州には数多くの建設実積を有 し，米国セントラルソーヤ社にも実施権を与えている。 わが国には 1963 年, 野田曧油(株)へミソ, ショウ油用 を目的とした $20 \mathrm{t} /$ 日 の加圧型大豆抽出機が輸入された が，1965 年 10 月千代田化工建設(株)がドイツエキステ クニック社と技術提携を行ない国産化されるに至った。

\section{$3 \cdot 1$ 原料の前処理}

$3 \cdot 1 \cdot 1$ フレークの厚さ

抽出機に供給される原料は一般に圧扁ロールでフレー 
ク化されたものを使用する。フレークの厚さを薄くすれ ば抽出時間は短くなり抽出機の大きさも小さくなるが， 圧扁ロールの性能, 抽出カスの用途, フレークの物理的 強度など考え, 大豆の場合には $0.3 \mathrm{~mm}$ を標準としてい る。大豆フレークの抽出カスを醸造用に使用するような 特殊な場合には，できるだけフレークの形を残すことが 要求されるので， $0.3 \mathrm{~mm}$ より厚いフレークを原料とす るが, この際の厚みと抽出時間は, 前処理工程に述べた Coats および Wingard の式7) により決めている。

$3 \cdot 1 \cdot 2$ フレーク中のファインの量

フレーク中のファインの量は, 原料層のミセラ貫流特 性を悪くすると同時に，チャンネリングを起こす原因と なり，抽出カスの残油率に悪影響を有するので，大豆の 場合は通常, ファインに対する制限規定を下記のとおり 決めている。すなわち,

○フレークの厚さは $90 \%$ 以上が規定の厚さ以下である こと。

○ファインの量は $0.4 \mathrm{~mm}$ のフルイを通過するものが 10\% 以下であること。

$3 \cdot 1 \cdot 3$ フレークの温度

抽出機に供給されるフレークの温度は前処理工程との

関係もあり普通 $50-60^{\circ} \mathrm{C}$ である。

\section{$3 \cdot 2$ カローザル抽出機（図-18 参照）}

\section{$3 \cdot 2 \cdot 1$ カローザル抽出機の構造}

カローザル抽出機は竪形円筒形の気密構造の本体シェ ルと, 内部に回転するセクショナルローター, セクショ ナルローターの底部をなし本体シェルに固定されている シーブボトム, 本体シェルの底を垂直のバッフルにより 数個の画室に仕切られて形成されるミセラ集合部, 最適 の抽出が得られるようにソルベントを原料層の上に散布 するミセラディストリビューターおよびロータ一駆動部 によりなる一段の抽出ユニットを目的に応じ 1 多段積
みかさね使用するものである。

内部を回転するセクショナルローターはフレークが充 テンされる所で，ローター上部に取り付けられたチェー ンにより全体が駆動され，無段減速機により30-240 min で 1 回転するように調節できる。ローターは内筒および 外筒よりなりその間を仕切り板にて区切り十数個のミ七 ラ循環のためのセルを設けていて，仕切板の下端にはナ イロン製のブラシが取付けられローターの回転ととも に，底のシーブボトムが清掃されるようになっている。 内筒にはシャフトが取り付けられ，ベヤリングを介して 本体に支持されている。底部のシーブボトムは本体に固 定され，ローターとは分離された構造である。シーブボ トムはウエットミールからミセラを完全に振切る役目の もので,ステンレス鋼製のウエッジワイヤスクリーンで, ウエッジワイヤーの各断面はクサビ形をなし，ミセラの 振切り，目詰りを防いでいる。また配列は内外筒と同心 円をなし，原料がその上を円滑に動くようになってい る。原料が抽出機に供給されセルに充テンされると，口 一ターの駆動によって，押され，シーブボトムの上を入 口側から出口側へ，各段の抽出を受けながら滑り，一回 転近く運ばれて出口に至り排出される。出口は簡単な落 とし口に過ぎないが押し出し式だから順序よく連続的に 下段の抽出ユニットまたは排出コンベヤーに落とされ る。こうして抽出の終わった抽出カスは抽出カスエレベ ーターで, D.T. (desolventizer toaster) に運ばれる。

ミセラ集合部の各室はそれぞれ各段階の抽出操作を形 成し，各段のステージポンプで，その室のミセラをミー ルの移動方向と反対の方向のつぎのステップのミセラデ ィストリビューターに送り，原料層の上㳻布する。原 料層を貫流し，シーブボトムより落ちたミセラは下部の ミセラ集合部にたまる。

このように抽出はいわゆる向流方式で行なわれ，新溶 剂はミールの最終ステップで供給され，油濃 度の最も高いミセラはミールの投入段階近く で得られフルミセラとなってただちにセット リングタンクに送られる。フルミセラの濃度 は通常25３5\%である。このほか本体シェル には各部に大きなワイパー付きサイト・グラ スが設けられ，また照明度の高いライトグラ スが装備され，内部の運転状況を完全に管理 できるとともに保守を容易にしている。

この抽出機とロートセル型抽出機のおもな 相違点は, ロートセル型のセル構造ではセル とスクリーンベッドが一体をなして抢り，同 時に回転するのに，この抽出機では，上述の ように，スクリーンベッドは本体シェルに固 定され, セルと切り離され, セルだけ回転 し，原料は，七ルに押されスクリーンベッド 
の上を滑っていく構造であることおよび抽出カスの排出 がロートセル型のようにヒンジ式ではなく，スクリーン ベッドに単に落し穴が設けられているだけの構造となっ ている点である。

以上のようにカローザル抽出機は, パーコレーション 型の理想的な向流連続抽出機である。

$3 \cdot 2 \cdot 2$ カローザル抽出機の特長

カローザル抽出機の特長をあげれば下記のとおりであ る。

1）上記のように, 構造が簡単でかつコンパクトであ り, 回転部分はローター軸だけで, 他の抽出機のように底 部を支えるローラーやレールも不要であるため, 全体的 に機械部品が少なく保守がきわめて容易でまた所要動力 も僅小である。したがって抽出機の価格も廉価である。

2) シーブボトムは同心円型のステンレス製ウエッジ ワイヤースクリーンで作られており，原料フレークは， ローターの駆動に伴い押され, このシーブボトムの上を 滑り入口側から出口側へ順次運ばれるため, シーブボト ムはフレークの移動に伴い, フレーク自体により掃除さ れ，目詰まりを生ずることがない。したがってミセラの フレーク層貫流特性がよいので抽出効率がよくまたミセ ラの振切りもよい。

3）この抽出機はきわめてフレキシブルな運転が可能 である。すなわちローターの回転速度の調節およびフレ 一クベッドの層厚を任意に変更することにより，運転条 件を自由に変更することができる。とくに雑穀のプレス ケーキなどファインを多く含むものは，ミセラの貫流抵 抗が大きくまたチャンネリングを生じやすいがこのよう な原料に対しても, フレーク層厚を薄くしミセラの貫流 量を多くすると同時に，このような際には 2 段型抽出機 を使用し上部より下段の抽出ユニットに，フレークを落 とすことにより, フレーク層を崩し, フレークに均一に 溶剤がかかるようにし，ほとんど完全に抽出することが できる。

4) 将来, キャパシティーアップする場合でも同じ抽 出ユニットを上に積み足すだけで们能である。

\section{$3 \cdot 2 \cdot 3$ 抽出力ス脱溶剤装置}

カローザル抽出機より, 排出された抽出カスは, 米国 セントラルソーヤ社のライセンスにより製作される。ス タック型の desolventizer toaster (図-16 参照)に運ば れ, 上部のケットルに供給され, 順次下部へ落とされて 行く過程で, 直接吹き込まれる生蒸気と接触し, 完全に 脱溶剂されると同時に液体溶剂と入れ換わって凝縮した スチームで均一に調湿加熱され飼料用に最適なミールと して取り出される。一方加熱蒸発された溶剤ベーパーと スチームの混合ベーパーは, サイクロン型のベーパー洗 条器で, 随伴するデンプン末を洗い落としたのち, ミセ ラ蒸留系へ送られる。最近は飼料用ミールの需要の伸び
が大きく, 大型の抽出装置は, いずれも, 本型式の D.T. (desolventizer toaster) が使用されようとしている。 カローザル抽出装置もミソ，ショウ油または豆腐原料な どの脱脂大豆を要求される場合にはこれとは違った desolventizer を個々の場合に応じて使用するようにし ている。

\section{$3 \cdot 2 \cdot 4$ ミセラ蒸留装置}

カローザル抽出機より出た, フルミセラはミセラデカ ンターで, 随伴のファインを除去したのち, ミセラフィ ルターを経て，ミセラタンクに送られ，ミセラタンクか らへッドにより第1蒸発カンに送られ 40〜60\% まで濃 縮される。第 1 蒸発カンの熱源には, カス脱溶剤系から くるwaste vapor が使用され，熱回収することによりス チーム, 冷却水原単位の低下に寄与している。第 1 蒸発 カンから出たミセラは第 2 蒸発カンでスチーム加熱によ り濃縮された後, オイルストリッパーで完全に脱溶剂さ れる。第 1 , 第 2 蒸発カン, オイルストリッパーはいず れも減圧下で操作され, 低い温度ですみやかにソルベン トを蒸発させ, 油の品質劣化を防止している。第 1,2 蒸発カンはいずれも薄膜上昇型を使用している。

\section{$3 \cdot 2 \cdot 5$ 溶剤回収装置}

本装置の溶剤回収装置としては, 吸収法を採用してい る。吸収法の採用は, きわめて吸収力の大きいミネラル オイル（エキン゙ーバーオイル）の発見に基づくもので, 本方法の採用により溶剤損失を極小にしている。

\section{$3 \cdot 2 \cdot 6$ 装置の所要面積}

抽出機はもちろん, 装置全体がきわめてコンパクト で, 所要面積, 建家が従来に比し, 非常に小さい。一例 を下記に示す。

大豆処理量 抽出機の大きさ 建家の大きさ

$\begin{array}{ccc}\mathrm{t} / \text { 日 } & \begin{array}{c}\text { 直径 } \times \text { 高さ } \\ (\mathrm{m})(\mathrm{m})\end{array} & \begin{array}{c}\text { 巾 } \times \text { 長 } \times \text { 高 } \\ (\mathrm{m})(\mathrm{m})(\mathrm{m})\end{array} \\ 100 & 3.0 \times 6.0 & 6 \times 8 \times 10 \\ 200 & 4.5 \times 9.0 & 6 \times 12 \times 11 \\ 500 & 6.0 \times 13.0 & 8 \times 15 \times 16\end{array}$

上記の建家は, 抽出機, ミセラ蒸留装置, 溶剤回収装 置が入るものである。

\section{$3 \cdot 2 \cdot 7$ 運 転 員}

通常一直当たり一人である。

\section{$3 \cdot 2 \cdot 8$ 装置の保証}

カローザル抽出装置は a) 項に示した前処理条件下で, かつ飼料用の脱脂大豆を作るとして, 運転值および保証 值は下記のとおりである。

\section{運転值保証值}
1) 残 油率 （フレーク厚み $0.3 \mathrm{~mm}$ において） $0.4-0.5 \% \quad 0.5 \%$
2) 溶用損失 $2-3 \mathrm{~kg} /$ 大豆フレ
3）蒸気消費量 $\begin{aligned} & 240-260 \mathrm{~kg} / \text { 大豆フ } \\ & レ ー ク \mathrm{t} \text { 当たり }\end{aligned}$
$\left(7 \mathrm{~kg} / \mathrm{cm}^{2} \mathrm{~g}\right.$ 飽和 スチーム) 
ただし抽出カスの NSI は $15 \pm 5$

とする
4）電力消費量 $6-10 \mathrm{~kW} \cdot \mathrm{hr} /$ 大豆フ
5）冷却水（下記の 3 case のいずれかとする）
5) -1 工業用水 $\left(20^{\circ} \mathrm{C}\right)$
$5)-2$ 冷水塔水$$
\begin{array}{cc}
10-15 \mathrm{~m}^{8} / \text { 大豆フレ } & 25 \mathrm{~m}^{3} / \text { 大豆フレーク } \\
\text { ーク } \mathrm{t} \text { 当たり } & \mathrm{t} \text { 当たり }
\end{array}
$$

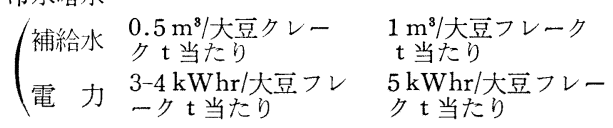
5)-3 空気冷却 コンデンサー

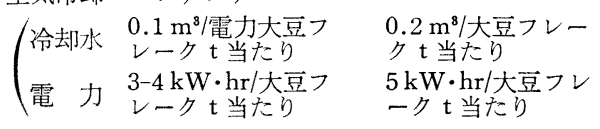

（昭和 42 年 2 月 8 日受理）

\section{文献}

1) “油脂”,

2) A.E. Bailey "Industrial oil and fat products" ch. 15 (1951)

3) K.S. Markley "Soybeans and soybean products" vol. 1 ch. 12,13 (1950)

4) A.E. Bailey "Cotton seed and cotton seed products" ch. 5,13 (1948)

5）平田，城塚 “抽出工学” p.357（1964）日刊工業新聞
6) 渡辺治男, 油化学, 12 (10), 549 (1963)

7) M.R. Wingard, J. Am Oil. Chemists' Soc., 36, 483 (1959)

8) G. Karhofsky, J. Am. Oil Chemists' Soc., 26, 570 (1949)

9) 玉置, 浜井, 新化学工学講座 “固体抽出”,

10) H.P. Kaufmann, Neuzeitliche Technologie der Fette und Fetteprodukte, 4 Lieferung. Aschendorffsche verlagsbuch handlung Münster westf.

11）高坂,ケミカルエンジニヤリング， 7, 1 (1961)

12) 矢野, 化学工学, 21, 241 (1957)

13) R.P. Hutchins, J. Am. Oil Chemists'Soc, 37, 674 (1960)

14) H.P. Kaufmann et al., p. 607, Neuzeitliche Technologie der Fette und Fettprodukte 4, Lieferung Aschendorffsche verlagsbuch handlung Münster westf.

15) E.A. Gastrock et al., Ind. Eng. Chem., 49, 920(1957)

16) A.V. Grain et al J. Am. Oil Chemists' Soc.; 30, 139 (1953); ibid., 31, 606 (1954); ibid., 32, 361 (1955); ibid., 33, 645 (1956); ibid., 36, 454 (1959); ibid., 38, 44 (1961)

17) U.S., 2.571, 143; U.S., 2,691, 830

18) Endre Sipos, N.H. Witte, J. Am. Oil Chemists' Soc., 38 ( 3), 11-19 (1961)

19) G.C. Mustakas, L.D. Kirke et al., J. Am. Oil Chemists' Soc., 39, 222 (1962)

\section{書 評}

"Progress in the Chemistry of Fats and other Lipids" Volume 8

Editor, Ralph T. Holman

Pergamon Press (全 436 ページ)

このシリーズはすでに定評のあるところであるが，その第 8 巻はつぎの 7 篇を収録する。Phospholipids and Biomembranes と題して L.L. van Deene によって関係文献 528 をあげた詳細な論説であり, ついで 最近のカロチノイド化学の進歩について Synn $\phi$ ve Liaaen-Jensen, Arne Jensen によってカロチノイドの分 離, 機器分析を中心にした諸性質および合成方法に関して 358 の文献をあげて総説している。以下の 5 篇は脂 質の分析方法に関するもので C.Y. Hopkins が脂肪酸の構造解析を中心にして NMR の基本的な応用を, John S. Showell が分子の異性体を含む立体構造, 特定結合と IR 吸収との関係ならびに偏光 IR および水素 結合に関してそれぞれまとめ, もっとも一般的な TLC 分析について Donald C. Malins が 211 の文献をあ げて脂質一般の基本的成分の同定より, 複雑な組成をもつものの定量, GLC やその他の機器分析との組合せ などについて総説し, James G. Hamilton がペーパークロマトグラフィーについて, 最後に Robert A. Stein, Vida Slawson が文献 236 をあげてカラムクロマトグラフィーに関して分別の対象となる脂質と, 吸着郕 と溶媒との組合せについてそれぞれ解説する。本書に収録せられる各篇はいずれもが豊富かつできるだけ新ら しい文献を引例として, 相当の分野で著名な学者によってまとめられたものであり, 日頃ともすればスポット 的になりやすい知見に明確な指針と筋のとおった概観とを与えてくれるものであろう。本書の冒頭にはとくに 編集者 Holman が偉大な足跡をのこされた T.P. Hilditch 教授をしのび本書をささげる旨の一文を寄せ, 写真ならびに F.D. Gunstone による業績の紹介が揭載せられる。Hilditch 教授の記念出版といら意義にお いても本書は価值あるものである。

(前橋和友) 